\title{
Chapter 8. Maori Meeting-Houses in and Over Time
}

\section{Toon van Meijl}

The landscape of New Zealand is remarkably European in character. Its folding surface is dyed with the verdant leaf of pastureland. Meadows are often marked out by hedgerows so typical of England. The grazing pastoral animals were all introduced from the northern hemisphere less than 200 years ago. Only the omnipresent Maori marae (ceremonial centres) remind travellers from overseas that they are, in fact, exploring a country in the South Pacific.

Marae are distinguished from ordinary localities scattered over the countryside by a meeting-house used by Maori people for various ceremonies and community assembly. Meeting-houses are the most outstanding indigenous feature of the landscape in New Zealand. As such they are often thought to antedate the advent of James Cook in 1769. However, there is no evidence to support this popular belief widely held among both Maori and Pakeha, the overall term for non-Maori. ${ }^{l}$ Neither Cook nor any other explorers of New Zealand in the late eighteenth century and early nineteenth century reported the existence of houses of a size significantly larger than average and belonging to the surrounding community at large. Moreover, the sometimes elaborately carved meeting-houses of the twentieth century bear little resemblance to the pre-European dwellings excavated by archaeologists.

In this paper I first describe contemporary meeting-houses, how and why they are built, and the symbolism that is embodied in their construction. Subsequently, I reflect upon standard anthropological analyses of the spatial orientation of meeting-houses, before analysing the temporal dimensions involved in the use of the house. I explain how various notions of time collapse into a conception of timelessness during ceremonies performed in the house. Furthermore, I argue that the sense of timelessness evoked during ceremonial gatherings must not be extended to the construction of meeting-houses themselves. To put it simply, the symbolism of meeting-houses may involve timelessness in some respects, yet the houses themselves have been and are subject to historical changes. An account of the development of meeting-houses over time is presented in the penultimate section, and I conclude with some notes on ongoing development in the future. I argue that in spite of the dramatic transformations of meeting-houses and their importance, they continue as the focal point of many Maori communities in both rural and urban areas. 


\section{The Marae}

Before I examine the fascinating symbolism of meeting-houses, I must first explain the concept of marae. Nowadays the term marae evokes two related meanings. In the first place, marae is used to denote an open space, a clearing or plaza in front of a meeting-house, reserved and used for Maori assembly, particularly ceremonies of welcome. This narrow meaning of the term marae is often distinguished as marae aatea or marae 'proper' (see Figure 1). In the second place, the concept of marae is used in the broader sense for the combination of the marae proper, the courtyard, with a set of communal buildings which normally include a meeting-house, a dining hall and some showers and toilets (Metge 1976:227). Marae are often regarded as the final sanctuary of Maori culture (Walker 1977).

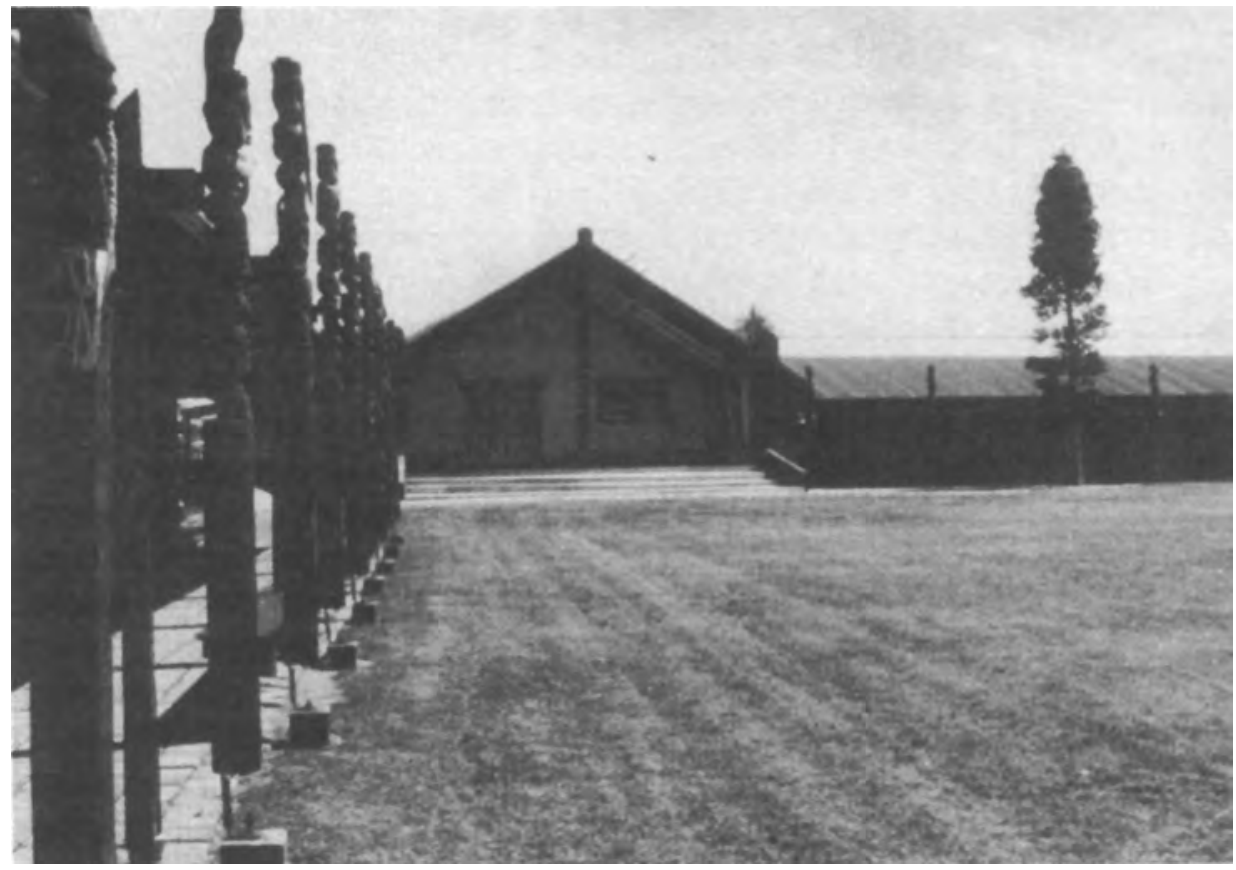

Figure 1. A view of the marae proper and the meeting-house Taane-i-ti-Pupuke at Waahi Pa, Huntly

In the 1980s only 10 per cent of the Maori population was based in rural communities. As a consequence marae are few and far between in the isolated villages scattered over the countryside. Generally marae are surrounded by only a couple of houses. Wherever they live, Maori people now occupy ordinary family houses of European design, each with its own modern conveniences. As a result, the marae is no longer used regularly as an extension to the private dwellings. Instead, marae are used only for ceremonial gatherings on occasions of life crises or especially to entertain guests. Under these circumstances the 
houses, that in pre-European days seem to have belonged to chiefs and their extended family only, have been enlarged and their ornamentation has often been refined as well. In addition, marae have been provided with a kitchen and a dining hall, with lavatories and shower facilities, all able to cope with large numbers of visitors.

Meeting-houses and marae are seen as 'going together' in more than one way (Metge 1976:230). Visiting orators commence their ceremonial speeches by greeting them both: Te whare e tuu nei, teena koe; te marae e takoto nei, teena koe (House standing here, I greet you; marae lying here, I greet you). Not only spatially, but also functionally, the meeting-house and the marae proper are complementary (Metge 1976:230). The marae is used for speech-making and welcoming guests during the daytime and in dry weather; the meeting-house is used to accommodate guests and for speech-making after dusk or on rainy days.

The complementary relationship between marae and meeting-house is often expressed by analogy with the gods of war and peace. Traditionally, so it was said, the marae was the area of Tuu-matauenga, the god and father of war, whereas the meeting-house was associated with Rongo-ma-tane, the ancestor of the kuumara (sweet potato) and the god of all other cultivated food as well as the god of peace:

Ko Tuu a waho; ko Rongo a roto

Tuu outside, Rongo inside (Metge 1976:231).

A contemporary rephrasing of the old saying I noted was voiced by a kaumaatua (respected elder), who explained to a group of young people that

the marae is the area of the good, the bad, and the ugly. The meeting-house, on the other hand, is the realm of Jesus Christ and the Kingdom of Heaven.

The elder intended to indicate that disputes are expressed and settled in the marae during the exchange of ceremonial speeches, while the conversation in the meeting-house after the welcoming of guests is not supposed to be about contentious issues. However, practice often proves otherwise.

\section{The Meeting-House Described}

A meeting-house is usually the dominant feature of any marae complex. It is a large rectangular building with a gabled roof and a front veranda, often, but certainly not always, marked by embellishments of carving, curvilinear rafter patterns (koowhaiwhai) painted in black, red and white with lattice-work panels (tukutuku) on the wall. Houses range in length from approximately 12 or 13 metres to nearly 30 metres. Both the size and the degree of ornamentation of a house say something about the mana (prestige) of its owner group. In myths 
there is evidence to be found that the size of a meeting-house adds to the prestige of the ones who built it (Salmond 1975:36). The size of a house also varies with the magnitude of the owner group. The house of a whaanau (extended family) will be smaller than the house serving a hapuu (sub-tribe). The other feature to be mentioned is the degree of decoration, particularly carvings, and here, too, prestige is at stake. However, it is important to point out that not all meeting-houses are necessarily carved. Only in some areas, particularly the east coast of the North Island, are most meeting-houses carved, whereas in the Waikato area where I did my fieldwork, for example, carved meeting-houses are extremely rare. Carving only came into fashion from the mid-nineteenth century on, and in that period of history, after the wars and confiscations of vast areas of land, few tribes had the means, let alone the morale, to become artistic.

Generally a meeting-house is built of modern materials. The foundations are embedded in concrete, the walls are made of weatherboarded timber and the roof is covered with sheets of corrugated iron. The front of the house is extended in the form of a porch or maahau up to 4 metres deep. When a meeting-house is richly embellished, this intermediate veranda, linking the marae proper with the interior of the house, is decorated the most with intricate carvings. An outstanding figure (tekoteko) is normally carved at the apex of the meeting-house. Some wood surfaces may be carved into ancestors or motifs derived from mythology, such as the infamous taniwha ((sea-)demons). The veranda rafters may be painted with the curvilinear koowhaiwhai patterns in white and black, and in some areas mixed with red. The doorway is to the right of centre, ${ }^{2}$ with the name of the house and often also the date on which it was formally opened, marked on a small panel fixed above it. Not infrequently the only window is in the front wall and to the left of centre. Along the walls of the veranda one might find wooden benches to accommodate visitors during hui, community gatherings for any purpose.

Inside the meeting-house old portraits of ancestors hang on the walls. Often the rafters rising from each side-panel to the ridge-pole are painted with koowhaiwhai designs, and under the roof there may be lattice-work panels between the rafters. The ridge-pole is supported by one or two freestanding heart-posts (the poutokomanawa), which, contrary to what Salmond reports (1975:37), are rarely carved into human figures, as, according to one informant of chiefly descent - an elderly woman of the Ngaati Porau tribe - Maori people do not recognize chiefs. 'This backbone of the house is not carved, because we don't recognize chiefs. We all carry the canoe together.'

In some houses there is a platform at the rear. The floor is usually covered with flax mats (whariki) or a carpet. Mattresses are stored against the walls or in a separate shed, and they are rolled out if the house is in use during hui. 
Visitors who stay the night in a meeting-house are provided with clean sheets and pillows.

\section{Social and Political Aspects}

The Maori name for a meeting-house varies according to its function at a particular moment: whare tupuna (ancestral house), whare runanga (council house), whare hui (meeting-house), whare puni (sleeping house), whare manuhiri (guest house), and sometimes whare tapere (house of amusement). As some meeting-houses have become increasingly ornamented with carvings since the last century, they may be referred to as whare whakairo (carved house) as well, but in my experience this term is rarely used, except perhaps when visitors or tourists are shown around. The primary function of the meeting-houses is one of shelter in case of rain or darkness. In addition it provides a community with the facility to accommodate up to 200 people. Greeting-ceremonies (mihimihi) and religious services (karakia) may be conducted in the house during formal hui. Oratory may be performed in the house during the evenings, followed by some entertainment before the lights are turned off and everybody goes to sleep. Apart from activities associated with guests at a marae, the meeting-houses are regularly used as a venue for meetings of the marae komiti (committee) or other community groupings.

In the meeting-houses owner groups, usually subtribes, symbolize their unity and their distinction from other subtribes. In that sense the meeting-houses were often built as a political counter (Salmond 1975:38). When a new subtribe emerged, when extended families bickered or community factions arose, the meeting-houses were erected to symbolize the newly developing social structure of a group. Many such cases have been reported, not all of them historical. I once visited adjacent marae of two relatively recent subtribes that used to constitute one united subtribe before World War II. Each marae had its own dining hall, but the two subtribes still shared one meeting-house. However, in contradistinction with normal etiquette, each group predominantly occupied one side of the house. For example, their dead were put either on the left or on the right side. Members of either marae mowed the lawns in front of the house only up to a symbolic boundary extending from the ridge-pole of the house. Children often played around the house, but when they accidentally crossed the invisible boundary they were smacked. Intermarriage between members of the two subtribes was not uncommon but definitely not encouraged either. Members of the two marae met only once a year, during the annual poukai, a 'loyalty gathering' of the Maori King Movement. On this day they attempted to outdo their rival group in offering the most lavish meal to the visitors, pledging loyalty to the Maori queen. Indeed, in this extremely rare case one wonders just when one of the two subtribes will decide to build a meeting-house solely for itself. 
The house as a symbol of solidarity of the kinship group is not new and may well antedate European settlement (Johansen 1954:27). More interesting, however, is the fact that the meeting-houses continue to be a most powerful symbol for newly emerging kinship groupings, which themselves are the result of an increasing disintegration of the kinship structure. In New Zealand, for example, there are clusters of several closely related, extended families scattered over the countryside. The core of these kin communities is formed by those who are descended, through either male or female lines, from a patriarchal head of no more than two or three generations ago. In some cases he may still be alive. The colloquial term for these kin communities is 'families', but in order to distinguish them from nuclear and ordinary extended families, Metge labelled them 'large-families' (1976:136-138). Since many large-families have erected a meeting-house to symbolize their autonomous status, they could also be called 'houses', to use the concept recently added to the anthropological kinship terminology by Lévi-Strauss (1982:163-187; 1987:151-152). Although he did not mention a link with meeting-houses, Lévi-Strauss (1987:178-184) applied the term to the Maori hapuu (subtribe) as well. However, in his theoretical consideration he pointed out that 'houses' are not equivalent to extended families, lineages (or in Maori society, subtribes) and clans (or tribes) (1987:151). Instead Lévi-Strauss argued that 'houses' take an intermediate position. He defined the house as

possessing a domain, perpetuated by transmission of its name, wealth and titles through a real or fictitious descent line which is recognized as legitimate as long as the continuity can be expressed in the language of descent or alliance or, most often, of both together (1987:152).

Lévi-Strauss added that in order to perpetuate themselves, houses make extensive use of fictive kinship, in terms of both alliance and adoption. Likewise, large-families or houses in Maori society were distinguished from subtribes because for practical purposes they included spouses and adopted children attached to the group. Nonetheless, large-families remained strictly limited in size and depth.

Lévi-Strauss (1982) also suggested houses may be a fairly recent phenomenon in the history of societies traditionally organized along kinship lines, but now 'in a situation where political and economic interest, on the verge of invading the social field, have not yet overstepped the "old ties of blood" ' (p. 186). In New Zealand the Maori houses emerged relatively recently as well, and, as yet, the dynamics of their development does not seem to have come to an end. After World War II large-families began building ancestral meeting-houses which in the past were invariably subtribally based. In the situation of the New Zealand Maori the meaning of Lévi-Strauss' concept of house is thus being enriched by the erection of meeting-houses to symbolize and reinforce the unity of the groups 
associated with them. The construction of meeting-houses by, and for, large-families or houses originated on the east coast of the North Island but is spreading across all areas of New Zealand.

\section{Symbolic Representation}

That meeting-houses are the most powerful symbol a group may possess is apparent from the meaning embodied in their form. They represent reverence for the past and deference to the ancestors of the subtribe or large-family concerned. Meeting-houses offer a statement that the ancestors are present when groups assemble at a marae. I will explore this symbolism on the three levels distinguished by Ann Salmond (1975) in her monograph Hui: a study of Maori ceremonial gatherings. While I follow Salmond's account closely, I often disagree with her analysis. Although ethnographically quite accurate, even brilliant at times, Salmond creates an ideal-typical view of what meeting-houses represent and the meaning she reads into them also represents her logical construction as anthropologist. There is too much evidence available to dispute the commonly accepted notion that meeting-houses represent ancestors, but, on the other hand, it is a fact that nowadays few Maori people are aware of all the symbolic conceptions that, according to anthropologists, are embodied in a meeting-house. Often I met Maori people reading books such as Salmond's classic work, and it would therefore be interesting to explore the question: to what extent have etic interpretations of meeting-houses been incorporated in emic discourse?

At the most general level, a remote but famous ancestor is represented in the meeting-house, after whom it is usually named. Salmond (1975:39) mentions that such an ancestor may have been, among others, an inhabitant of the mythological homeland Hawaiki. This was what the people at the marae where I lived told me as well. However, nobody knew anything about him. In my attempts to find out who Taane-i-te-Pupuke had been, I was initially unsuccessful until one of the more senior elders told me the ancestor after whom the meeting-house was named had been a paramount chief in Hawaiki. He added that he had not been able to tell me about him beforehand, because anything coming from Hawaiki was highly tapu (sacred; see pp.203-207). ${ }^{3}$

Meeting-houses are not only named after an ancestor. Their structure represents the body of an eponymous ancestor too. The koruru at the junction of the eaves of the veranda represents his face. The porch itself is regarded as his brain (roro). The barge-boards (maihi) are his arms, while the extensions of the barge-boards, called raparapa, represent his fingers, as carvings sometimes suggest. The front window is seen as his eye (mataaho). The interior of the meeting-house is the chest (poho) of the ancestor. The ridge-pole (taahuhu) is regarded as his spine representing the main line of descent from the apex of the (sub)tribe's genealogy. The rafters (heke) are his ribs representing junior descent lines derived from the senior line (taahuhu). Heke means literally 'descend' or 
'diminution', but in the meeting-house it bears connotations of 'my line as distinguished from your line' (Webster 1975:140). The structure of the meeting-house evokes the concept of welcome according to Salmond (1975:40). She interprets the eaves as arms 'held out in welcome', and she argues that it also explains why the door is always left open during gatherings. However, since the early 1980s the door of a meeting-house is no longer left open unless a Maori warden is available to keep an eye on the house when the visiting crowd is in the dining hall; otherwise the house, with all the belongings of the visitors, would be ransacked by children and youngsters playing around the marae.

At the second level, within the house the poupou (slabs) from which the heke extend, ideally represent junior ancestors descended from the founder. Salmond (1975:40) automatically assumes that slabs are carved and that they are 'ancestors within the ancestor'. She argues that the slabs constitute a genealogy around the walls. However, in many meeting-houses slabs have not been carved and I am not sure whether in that case they are still associated with a particular ancestor. I suspect they are not. When the slabs are carved, though, they often represent ancestors directly related to the group. In some cases they may symbolize the patriarchal heads of the extended families associated with the subtribal marae, and the number of slabs should ideally accord with the number of extended families. In older meeting-houses the carved ancestor on each slab may be recognized by a distinctive feature that portrays his character, but nowadays few people know enough history or mythology to interpret these without controversy. Hence, in more recent meeting-houses the name of the ancestor is marked on the slab. Not all the figures depicted in the poupou relate to the genealogy of the subtribe (Kernot 1983:191; Neich 1984:7-9). In Te Awamutu I visited a brand new meeting-house in which a number of Pakeha historic figures were carved, including a military officer, General Cameron; a colonial official, Sir John Eldon Gorst; and the first Anglican bishop, Selwyn; all of whom had played a significant yet not necessarily positive role in colonial history. This is a telling example of how Maori people have accommodated foreign elements in their traditions and changed these according to circumstance.

Finally, ancestors are represented in Maori meeting-houses by photographs hanging on the walls, particularly the front wall. These portraits constitute the representation of the most recent forebears. In the past, Salmond (1975:41) reports, photographs were put in order by the kaumaatua (elders) of the marae, who arranged them according to family affiliations. The people portrayed in the house are invariably of superior rank or status. Usually a portrait is taken into the house for the first time after a person's death. During the tangihanga (the funeral wake) photographs of the deceased are placed at the end of the coffin and around it, along with those of male and female ancestors as well as of other close relatives and friends who have died. After the tangi they may be taken back to the dwelling where the deceased used to live until the unveiling of the 
tombstone, normally one year later. On this occasion the portrait of the deceased replaces the open coffin. It is placed on flax mats spread out on the veranda. The family and visitors assemble in the porch of the meeting-house for a memorial service. They weep over the picture as they had done over the coffin a year before. Subsequently they move on to the cemetery to unveil the stone.

In summary, the portraits, like the carved slabs and, at the most general level, the structure of the meeting-house itself, can be regarded as substitutes for the forebears they represent. During ceremonies in and around the meeting-house the most recent, the more remote, as well as the most remote ancestors are present in both spiritual and physical form (Salmond 1975:41).

\section{Spatial Orientation}

Cross-cutting the symbolism of ancestors in meeting-houses and the different temporal dimensions involved in this representation is a spatial orientation which has more effect on the practical use of meeting-houses. This is the complementary distinction of various parts of the meeting-house into tapu (sacred) and noa (common) dimensions. Tapu and noa are obviously exceedingly complex concepts with which anthropologists could not come to grips for a long time, but since the brilliant analysis by Michael Shirres (1982) it is beyond doubt that the greatest contrast is not between tapu and noa but between 'intrinsic' tapu and 'extensions' of tapu, or simply between more and less tapu. An exhaustive application of this pioneering insight is beyond the scope of this paper, although a preliminary attempt is made to explore the consequences of Shirres' conceptualization of tapu for the analysis of the meeting-house. However, since the concepts of tapu and noa are essential to the understanding of most aspects of marae layout and usage, I will first explain their relevance in general.

As a whole, the marae complex is regarded as tapu in relation to the outside world (Metge 1976:232). When a group of visitors arrive at a marae, they will wait at the gate entrance (tomokanga) until called to enter. In the shrill high-pitched call of welcome (karanga) always recited by a woman, often words that mean 'come up' rather than 'come in' are used: piki mai, kake mai, eke mai (climb, ascend, rise; Figure 2 shows a group of people doing a powhiri, a part of the welcoming ceremony immediately after the karanga). Although in former days Maori paa (strongholds) were often located on top of a hill, nowadays most marae are flat, and therefore it is obvious, as Metge (1976:232) points out, that the climbing is a symbolic movement. 


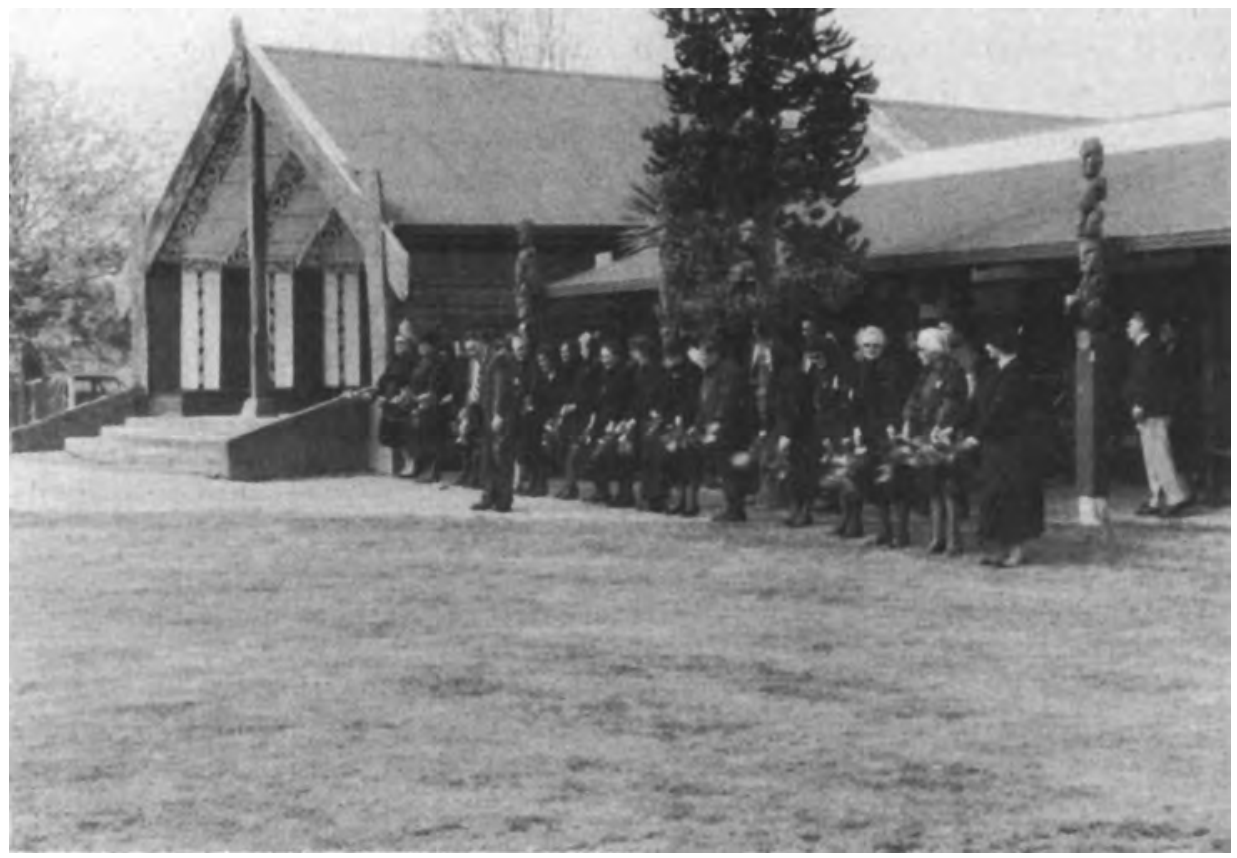

Figure 2. Welcoming a group of visitors in front of the meeting-house Taana-i-te-Pupuke at Waahi Pa Marae in Huntly

Within the boundaries of the marae complex a number of complementary domains are distinguished. Between these domains there is some tension that originates in the distinction between more tapu, less tapu and, to some extent, noa. Thus the marae aatea, or marae proper, and the meeting-house are often distinguished as the tapu sector compared to the dining hall and kitchen which are regarded as noa. At the same time, however, each is internally differentiated into complementary parts representing intrinsic tapu, the extensions of tapu and/or noa qualities. Without doubt the most tapu part of the marae complex is the central part of the marae proper, the area on which the ceremonies of welcome are performed and where orators make their speeches. It is one of the most serious violations of marae protocol and of tapu to walk across this area during a ceremony or speech. Even when the marae proper is not in use it should be treated with the utmost respect, although this is no longer obvious to Maori youths. Where I lived old people could not get the boys to understand that it was disrespectful to play football on the marae proper. By the same token, I remember some old people nearly having heart attacks when a Pakeha social worker laid down to sunbathe on a marae proper during a bicultural gathering. By comparison the meeting-house as well as the areas surrounding the marae proper, where people take up a position to listen to the speeches, are less tapu than the marae proper. However, they can never be noa because they are allegedly opposed to the intrinsically tapu courtyard, as Metge (1976:232) would 
like us to believe. ${ }^{4}$ Tapu and noa do not constitute a complementary opposition. They are surely complementary, but merely as distinctions mediated by extensions of tapu.

In regard to the meeting-house itself there are a number of practices that exemplify its intrinsic tapu qualities. The meeting-house is most tapu while it is being built, and in the course of its construction neither women nor food, which are far from intrinsically tapu - even noa under certain circumstances - are allowed entry. Even after the meeting-house is opened, food is never to be taken inside.

Within the meeting-house the first distinction that can be drawn is between the mahau (the open-air veranda) and the interior (Salmond 1975:45). Since the veranda marks the transition between the marae proper and the meeting-house, it is used in a distinctive manner. Salmond reports that at a funeral wake (tangihanga), the coffin, which is one of the most tapu objects one can think of, used to be placed in a small shed or marquee to the left of the entrance to the house in order to avoid contaminating the building. Nowadays, however, the coffin is either put on the veranda under the window or taken inside the house. In some areas people still seem to be reluctant to take the coffin inside and this may indicate a fundamental difference between the veranda and the interior. The veranda could be more tapu for some reason or another. ${ }^{5}$

The passage from veranda to interior is made through the door by the living, and, in some more traditionally oriented areas, through the window by the dead (Salmond 1975:46). In the Urewera district, where the Tuhoe Maori people reside, the window is regarded as highly tapu and therefore the coffin, if it is taken inside the house at all during a funeral wake, is passed through the window. The door is said to be less tapu and it is not believed to present a risk to the living, who may pass through it without hindrance.

When entering the house, even in museums where visitors are still expected to revere the meeting-house, one custom is widely practised: the practice of removing shoes at the door and entering with bare feet or socks. This is said to reflect the tapu state of the house, and Salmond (1975) quotes an informant as saying that people should take off their shoes because 'your boots have been walking outside, into the whare kai [dining hall] and all sorts' (p.46). However, it is more likely to reflect concern for the flax mats or the carpet on the floor of the meeting-house than to have something to do with tapu. I recall a well-respected woman who told me when I was hanging about a meeting-house: 'Hey, Pakeha, you take your shoes off in the house of the horis, ${ }^{6}$ hey'. Subsequently she proceeded to enter the house with her shoes on.

Inside, the meeting-house is also divided into two separate yet complementary domains: the tara whaanui (the 'big' side) and the tara iti (the 'little' side), which 
are related as more and less tapu. The boundary between the big side and the little side extends from the doorway which is generally to the right-hand side of the house. Consequently, the tara whaanui, or big side, lies to the left of a person, and the tara iti, or little side, to the right. When guests are accommodated in the meeting-house, they are placed along the left wall and across the tara whaanui, the more tapu side, which is reserved for visitors. The local people (tangata whenua), the 'people of the land' or the 'hosts', sleep on the tara iti to the right (Metge 1976:232).

Surprisingly, Salmond (1975:47) does not mention the distinction between the big side and the little side, although she reads a whole range of other symbols in the obvious distinction between left and right sides inside the meeting-house. She writes that at some places the doorway lintel is surmounted with a carved panel representing a female ancestor (pare), which leads her to conclude that the right side of the house is noa and associated with the living (p.47). The fact that the carving, as she wrote on the previous page in another context, usually represents the goddess of death, Hine-nui-te-Poo, does not appear to her as contradictory (cf. Jackson 1972:40-60). Further, Salmond writes that the window, being the entrance to the house on the left side, is said to be tapu and dedicated to the use of the dead (p.48). This holds true in the case of funeral wakes. Coffins are placed on the porch to the left of the house under the window, or if taken inside they are laid down somewhere on the left side of the house (depending on the tribal area) either under the window, at the window end of the left wall, or just in the middle. The intrinsically tapu body always stays on the more tapu side.

Within the spatial orientation of meeting-houses special places of honour were allocated to people of highest rank. It was, but no longer is, a rule, as Salmond (1975:48-49) has it, that the most distinguished guests at a hui were placed to sleep under the front window. The position was referred to as iho nui:iho having connotations of 'essence', 'strength' or an 'object of reliance'; nui meaning 'big' or 'large'. The local chiefs lay down to sleep to the right-hand side of the front door, which was called the kopa iti position: kopa evoking associations with 'weak' or 'numbed'; iti meaning 'small' or 'unimportant'. However, nowadays the more prominent visitors do not necessarily sleep at the former positions of honour up front. Metge (1976:234) mentions that people of highest rank are now usually placed under the recently introduced windows at the rear, away from traffic in and out during the night. However, at the marae where I was based, the door to the nearest lavatories was in the rear wall as well. There chiefs usually just slept somewhere in the centre of the house.

In the meeting-house the placement of a coffin, of visitors and locals, of prominent visitors and local chiefs, and, in some contexts, of men and women, was generally no accident. It did and, up to a point still does, relate to a scheme 
of spatial orientation characteristic of the marae which distinguishes between intrinsic tapu, extensions of tapu, and noa domains. However, it is important to point out that the principles of spatial structure are now expressed only by a few expert elders and a number of anthropologists.

\section{Temporal Implications of Spatial Orientation}

In a more recent consideration of semantic associations of some key concepts in the Maori world-view, Salmond (1978:9-11) discovered a link between the temporal and spatial orientation of the meeting-house. She noted a contrasting opposition between the meanings of 'front, past time, sacred place, seniority of birth' and the meanings of 'hind part, rear, future time, noa (unrestricted, profane) place and cooked food, junior birth, north and death' (p. 10). In the Maori language the past was described as ngaa raa o mua, 'the days in front', whereas the future was 'behind', kei muri (Metge 1976:70). Maori people moved, as it were, into the future with their back to the front while facing the past. The spatial orientation of the Maori concept of time concurs with Salmond's interpretation (see pp. 10-14) of the symbolism of the meeting-house as a progressive time sequence from the remote past - with the house itself representing the eponymous ancestor, who ideally stands at the apex of the subtribe's genealogy - through the intermediate stage of the ancestor's descendants represented in the carved slabs along the interior walls, to the stage of portraits figuratively depicting recently deceased kin members. In addition, the place of the sacred seniors (past) in the front and the more junior (future) towards the rear of the house, corresponds with the temporal succession from remote past to more recent past, toward the future.

The linear progression over time that takes place when entering the meeting-house may, to some extent, be condensed to a contrast between a mythological past outside of the meeting-house and a more historical past in the interior of the house (Neich 1984:34). The transition from the world of myth to the world of history was marked by the doorway which was recognized as a tapu boundary. In fully carved meeting-houses the threshold was marked with a carved slab, or pare, over the door (Jackson 1972:40-60). Many pare depicted a female figure with her legs outstretched, often representing the goddess of death Hine-nui-te-Po. ${ }^{7}$ The pare indicated its function of lifting the tapu of anyone entering the house (Salmond 1975:46). Nowadays the pare has been replaced by a small sign with the name of the house painted on it.

Interestingly, the linear progression from the mythical world of the ancestors in front of the meeting-house to the historical past inside, leading toward the future at the rear of the house, is an inversion of the symbolic implications of the movement into the house as a transition into the timeless, ever-present world of the ancestors. The spatial orientation of the meeting-house with the remote past outside, to the more recent past inside and the future towards the rear, 
seems to be reversed in the metaphor of the movement into the house as an apparent regression in the past. After all, the future (kei muri, rear) was behind the people moving into the house, pushing them forward into the past (mua, front). When moving into the house the future was, thus, resolved in a meta-historical past, while the past repeated itself in the future.

The inversion of the temporal implications of the spatial orientation of the meeting-house when entering the house, signifying the spiritual realm of the ever-present ancestors, can only be understood in relation to the Maori conception of time and their view of history (see Neich 1984:32). In the Maori world-view time was intimately linked up with natural events and processes. Time was not yet hypostatized into generalized, quantifiable periods independent of human action. Time was relative rather than absolute, concrete rather than abstract. By the same token, the Maori view of history was characterized not by a quest for abstract continuity in an infinite stream of events, but by an appraisal of concrete events in their own right:

to us the event - apart from picturesque aspects - is of no value until it stands as an expression of the forces of history and their conflicts; to the Maori the event in itself is so significant that history obtains a full meaning simply by consisting of events (Johansen 1954:151).

Thus, separate historical events acquired a meaning fundamentally different from the meaning they have in Western conceptions of history: 'We find it quite obvious that when an event has happened, it never returns; but this is exactly what happens' (Johansen 1954:161). Consequently, in the Maori world-view history unfolded as a return of the same experiences: 'We cannot underline the literal meaning too much when we say that the Maori relives history' (Johansen 1954:161).

The continuous regeneration of historical events explains the relevance of ancestors. They were still present to support and guide their descendants. Hence they were spoken of in the present tense as well (Metge 1976:70). Ancestors lived on in the history of kinship groups and as such their lives were the same as those of the living (Johansen 1954:163). Ancestors reappeared in the living as history emerged and was actualized.

In the recurrent manifestation of the same events and experiences, different conceptions of time collapsed. The point may be illustrated by an analysis of the act of entering the meeting-house. As pointed out above, the doorway of meeting-houses was highly tapu. In old meeting-houses the boundary was marked by a carved pare (lintel) over the door to signify the linear transition from the timeless world of myth to the historical world of ancestors. However, the same movement symbolized a return to the eternal past of ancestors. In other words, the movement into the house paralleled a progression in linear time, but the 
arrival in the historical world of the ancestors involved a constant regeneration and ceremonial recapitulation of their legendary past. The Maori attempted to resolve the present in the past while simultaneously calling upon the ancestors for guidance and spiritual support to make the future accord with their heroic past. Ultimately, in the ideal model of the cosmos, the past, the present and the future collapsed. In the meeting-house all time was made one (see Jackson 1972:61).

Thus the Maori material offers some evidence for the hypothesis formulated by Maurice Bloch (1977) in a brilliant article on the relation between a cyclical notion of time in ceremonies and rituals, and linear time in practical activity. The practical act of entering the house was associated with a linear progression from myth to history, whereas the ceremonies in the house involved a (cyclical) recurrence of the spiritual past in order to invoke a dimension of timelessness. In so far as the present is a mere recapitulation of the past to make it channel the course into the future, in the Maori world-view different notions of time were collapsed.

\section{Transformation of the Meeting-House Over Time ${ }^{8}$}

The meaning of timelessness as generated during gatherings in the meeting-house is often extended to the house itself. At a funeral wake a respected elder (kaumaatua) formally welcomed the anthropologist and apologized for the noisy children running around playing with dogs. 'But', he said, 'it is like the house, it is part of our life-style and will never change'. The elder implied that meeting-houses had been in existence from time immemorial expressing a popular belief widely entertained in New Zealand. ${ }^{9}$

However, although meeting-houses invoke a cosmic timelessness through a collapse of the past into the present to assure the continuation of the past through the present into the future, the construction of meeting-houses itself clearly follows a non-timeless, historical transformation. Archaeological evidence reveals that large carved meeting-houses as described by explorers from the 1830s onward did not exist before the arrival of Europeans. The type of house most common in prehistoric times was generally of a significantly smaller size. However, a difference in size between pre-European Maori dwellings was reported as early as 1769. James Cook noted that some houses were twice the size of others and suggested that

this depends upon the largeness of the Family they are to contain, for I believe few familys are without such a House as these, altho' they do not always live in them, especially in the summer season, when many of them live dispers'd up and down in little Temporary Hutts, that are not sufficient to shelter them from the weather (1968:223). 
Cook's account conveys the impression that the main difference between houses was the range in size. Other explorers, however, described some ornamentation with carving as an additional feature of the houses that were larger than average (see Groube 1964:89). These houses were identified as chief's houses. In addition, the early records suggest they were used as sleeping-houses (whare puni) for the chief's family, and to some extent also for community gatherings.

The whare puni appear to have a long history. In the early 1970s the New Zealand archaeologist Nigel Prickett (1987) excavated the oldest specimen of this type of house yet found. The dwelling excavated in the Moikau Valley in south Wairarapa dates back to the twelfth century. It was rectangular in plan with a partly enclosed front porch and the door left of centre, thus indicating that spatial orientations of the Maori may have been in existence six or seven centuries ago (Davidson 1984:153). This type of house clearly resembles the whare puni of later ethnographic accounts by, for example, Elsdon Best (1941, II:558-592) and Raymond Firth (1926).

However, Firth began his article entitled 'Wharepuni: a few remaining Maori dwellings of the old style' by pointing out the difference between the whare puni and the modern meeting-house, the carved house (whare whakairo), as described by Williams (1896). Firth (1926:54) denoted the latter as 'the property only of a man of rank'. The whare puni was instead owned by 'common people' or 'plebs'. Firth made a clear distinction between the whare puni and whare whakairo, which he linked to a difference in social status between the people to whom they belonged. He also indicated that the whare whakairo were of recent origin, but he did not place the distinction in an historical context. Since Firth wrote his essay on the whare puni, however, times have changed.

At present it is widely accepted that (carved) meeting-houses (whare whakairo), although they roughly follow the plan of whare puni on a larger scale, are a post-European development. The architectural design of modern meeting-houses may originate in the pre-European era, but the really large and elaborately carved meeting-houses, as distinct from the chief's dwelling or whare puni, became a dominant feature of Maori settlements only under the new conditions of the nineteenth century (Davidson 1984:151-160).

In his pioneering MA thesis, the New Zealand archaeologist Leslie Groube (1964) formulated the hypothesis

that much of the change in Maori material culture which has been assumed to be prehistoric may in fact have taken place in the protohistoric period from the stimulus given to Maori culture by the arrival of European ideas and technology (p.16-17). 
Groube substantiated his proposition, among other things, with an analysis of the development of meeting-houses in the early nineteenth century. He compared and contrasted accounts of the first missionary, who arrived in 1814, with reports written in the 1830s, and noted a significant increase in size as well as in ornamentation. While original chiefs' houses were rather plain and were used primarily as domestic dwellings, the houses built in the 1830s were more elaborately carved and they served in the first place to accommodate guests, particularly white explorers, traders and whalers (Groube 1964:120). Soon after the missionaries arrived the chief's house acquired new functions, and from the specialized use of the whare puni, the much larger, often fully carved whare whakairo developed. Thus the meeting-house emerged from the domestic level of an extended family of superior rank to the level of the community.

The modern style meeting-house was first developed in the Bay of Islands in the far north of the North Island, where colonial trade and settlement commenced. The increase in size and also the more detailed elaboration of carving designs were probably the result of better wood-working tools introduced by the Europeans (Groube 1964:118). The fact that they did not spread to southern regions until after 1835 (Groube 1964:122) offers some evidence for the hypothesis that they most likely were built to persuade missionaries and other Europeans to settle among them.

\section{The Influence of Pakeha Patronage}

In the course of the nineteenth century the whare whakairo gradually replaced the whare puni. It received more artistic attention and acquired novel functions in the swiftly changing dimensions of religion and politics. However, during the late 1800s the number of large, carved meeting-houses being built markedly declined. The size of the Maori population approached an absolute low through loss of land following the New Zealand wars of the 1860s, through famine and raging epidemics, and through a fundamental dislocation of the Maori morale. It was commonly believed that the Maori people as a 'race' were doomed to extinction in the near future. The general despondency marking this period generated a special interest in Maori art among European art collectors. If the Maori people were dying out, so they believed, Maori culture must soon die out as well. This stimulated them to make an effort to preserve Maori art and culture. The extent to which these European patrons had a direct impact on the further transformation of the whare whakairo is a most interesting issue.

In his analysis of changing carving styles in the centre of the North Island, Roger Neich (1983) argued that around the turn of the century in Rotorua a rather 'orthodox doctrine' about traditional Maori art was formulated by two European art collectors: C.E. Nelson, the manager of a tourist hotel in Rotorua, and Augustus Hamilton, the director of the Colonial Museum in Wellington. In order to salvage traditional Maori culture, these two men employed a number 
of Maori carvers to build and ornament meeting-houses for display and tourist use. Their commissions were rather detailed, including particular instructions with regard to certain carved items. If these were not to their satisfaction, they did not hesitate to correct the carvers. Thus figures with heeled boots as introduced after contact were removed as inauthentic and carved with the more genuine feet and toes (Neich 1983:257-259). Celebrated characters from super-tribal mythology replaced the tribal ancestors to make the carvings easier for tourists to understand (Neich 1983:259). Both Nelson and Hamilton obviously held strong views as to what genuine Maori culture had looked like in the past, and as patrons of the Maori carvers they specifically requested them to carve in what was supposed to be the most traditional way. Nelson even liked to be known as the 'white tohunga' ('expert'). One journalist characterized him as 'more Maori than the Maori' (see Neich 1983:255).

The basic assumption in Nelson's and Hamilton's quest for the authentic was that traditional Maori culture had remained unchanged since the time of discovery and settlement of Aotearoa, the land of 'the long white cloud' as the Maori allegedly named New Zealand when they first set foot ashore between 1000 and 1500 years ago. From their point of view change had only commenced with the advent of European missionaries and settlers in the early nineteenth century. As a result of European contact Maori culture had fallen into decay, which in the second half of the nineteenth century was increasingly explained by Darwin's theory of evolution (Howe 1977:140, 142). The vanishing of the Maori was an inevitable result of natural selection following the advance of European civilization.

Interestingly, however, the meeting-houses built under the guidance of Nelson and Hamilton, and particularly the accompanying carvings, displayed some innovative features that have become firmly entrenched in the carving tradition since then. The orthodox doctrine, as developed by Europeans committed to the preservation of the putatively pre-European Maori culture and art, ironically enough, entailed a new style of carving to portray Maori culture in its most traditional, authentic form. The link between form and content was finally disconnected. Aspective representation was gradually substituted by perspective representation. And the artist became more self-conscious regarding the transformation of his vision of the world in an art-object (see Neich 1983:260).

Over the years the style of carving used in the meeting-houses that were erected under the supervision of Nelson and Hamilton has become the prototype of traditional Maori art. ${ }^{10}$ Thus emic models of Maori tradition have been affected by etic interpretations. Contemporary Maori art and craft has been fundamentally influenced by Pakeha conceptualizations of pure Maori culture that developed around the turn of the century. The influence of etic models, however, was not restricted to the domain of art, but rather originated in an emerging theory of 
the whence and whither of the Maori (Sorrenson 1979). Implicit in the new ideas about the voyage of the Maori from mythological Hawaiki to Aotearoa was the assumption that from the moment of settlement no change had taken place. Maori culture was portrayed as static. Now, by replicating traditional items of carving and building meeting-houses in the ancient style, Maori culture had to be transformed into a timeless culture, so that the past would never disappear in the future.

The conceptions of time involved in this discourse about the Maori past have proved tenacious. The tenets of this mode of thought have haunted not only views of art and carving but overall discourse on Maori culture as essentially comprising relics of a distant yet eternal past. Even though Maori culture may seem to have been superseded by modern civilization, it is conceived of as unchangeable, as timeless. Meeting-houses are just one, albeit one of the most conspicuous, of the elements of this ideology.

\section{Concluding Remarks}

The fact that the tradition of building and carving meeting-houses was given a crucial impetus by a number of European art lovers, who as tourist entrepreneurs and museum directors had a vested interest in the continuation of Maori material culture, should not lead to the conclusion that meeting-houses are any less important. Only when meeting-houses are seen as 'inauthentic', could it be argued that they are insignificant. However, the notion of inauthenticity proves highly problematic when a long-term perspective of change is taken into account. Archaeological evidence suggests that meeting-houses developed out of pre-European sleeping-houses of chiefs and which were, among other things, to tempt Europeans to settle in a Maori community. At the time they replaced the war canoe as a focus of group pride (Neich 1983:247).

In spite of the transformation of meeting-houses over time, the spatial orientation of their structures and their temporal implications persist. Even the distinction between intrinsically tapu domains, their extensions and their noa counterparts continues to play a role in contemporary Maori people's lives. Since contact, tapu observances may have been progressively phased out of people's daily lives. Today, too, tapu and noa may be unknown as concepts to many Maori youngsters. However, many people, including young people, still follow tapu rules in their homes, although they are often unaware of the implications of their own practices. I will never forget the moment I was admonished by a little Maori boy, barely five years of age who told me I should not wash my hands in the kitchen sink, but who could not tell me why. By the same token, many people are still reluctant to wash teatowels in the same machine as they use to wash underwear. Children playing in meeting-houses are still taught never to sit on pillows on which you put your head, since the head is considered to be the most tapu part of the human body. Little girls know from an early age 
that they may never step over someone lying on the floor in the meeting-house, not even over the legs. Thus tapu is far from insignificant in day-to-day interaction, but it is no longer legitimized in traditional Maori terms.

To the extent that tapu and noa are still consciously present, they are, like a great deal of Maoritanga, increasingly relegated to the marae. The marae is the place where tradition is respected and relived. People who can no longer relate to their traditional roots feel alienated from a marae environment and will never go there, while those who find it a model for contemporary reality might prefer to stay there. They might regard the marae as the final refuge of Maori culture.

Within the marae complex it is the meeting-house which is the focus of activity. As the marae has changed over the years, so too has the meeting-house; it is being changed in contemporary constructions of new meeting-houses (Kernot 1983), and it will continue to change in the future. Hence the notion of timelessness, so important in contemporary experiences of the meeting-house, should not be extended to the construction nor even to the symbolism of the house itself. As mentioned before, not only is the erection of carved meeting-houses a post-European development, the interpretation of the meeting-house as a representation of an ancestor and the entire ancestor cult may also be of recent origin. And, of course, not only will the architectural design of meeting-houses continue to change in the future but also the interpretation of their symbolic representations.

I was given a foretaste of a possible change of direction in the symbolic interpretation of the meeting-house by the following event. I overheard a respected elder explaining the meaning of a meeting-house to a group of senior European (Pakeha) managers on an introductory course in Maoritanga or Maori culture. He told them the structure of meeting-houses was based on a canoe turned upside-down. The elder added that the canoe constituted one of the most spiritual concepts of the Maori people because they had travelled by canoes from mythological Hawaiki to New Zealand, and, he said, 'we still refer to people from other tribes as the descendants of the crew of a particular canoe. It is a living thing, you know. It is not within you. You are it yourself'.

To make sense of his rather unconventional explanation of meeting-houses, I ought to inform the reader that the narrator was trying to organize the descendants of the crews of all the 'canoes' (waka, currently a 'confederation of tribes') that had migrated to New Zealand to build another canoe at a site in Auckland that would be accessible to tourists during the period of construction and carving. The canoes were to be built over the six months preceding 6 February 1990 when they would embark on a voyage to Waitangi in the far north of the North Island to commemorate the 150th anniversary of the signing of the Treaty between Maori and Pakeha. With the blessings of the Maori queen the Maori elder was trying, symbolically, to reunite the various Maori 
(super-)tribes or canoes in opposition to the Europeans. His mind was preoccupied by canoes, which caused him to invent a new way of looking at meeting-houses. It indicates that the representation of ancestors possibly could be replaced by the original focus of group pride, the symbol of the canoe, or, at least, that the canoe may reacquire a prominent position as a rallying symbol for Maori tribes.

\section{References}

Best, Elsdon

1941 The Maori (2 volumes)(Memoirs of the Polynesian Society, Vol. 5). Wellington: The Polynesian Society. (Orig. 1924.)

Bloch, Maurice

1977 The past and the present in the present. Man 12:278-292.

Cook, James

1968 A journal of the proceedings of His Majesty's bark 'Endeavour', on a voyage round the world, by Lieut. James Cook, Commander, commencing the 25th May, 1768. In Captain W.J.L. Wharton (ed.), Captain Cook's journal during his first voyage round the world made in H.M. bark 'Endeavour' 1768-71: a literal transcription of the original MSS, pp.129-230.

Adelaide: Libraries Board of South Australia. (Orig. 1893.)

Davidson, Janet

1984 The prehistory of New Zealand. Auckland: Longman Paul.

Firth, Raymond

1926 Wharepuni: a few remaining Maori dwellings of the old style. Man 26(30):54-59.

Goldsmith, Michael

1985 Transformations of the meeting-house in Tuvalu. In Antony Hooper and Judith Huntsman (eds) Transformations of Polynesian culture (Memoirs of the Polynesian Society, No. 45), pp.151-175. Auckland: The Polynesian Society.

Grey, George

1971 Nga Mahi a Nga Tupuna. Wellington: Reed. (Orig. 1854.)

Groube, L.M.

1964 Settlement patterns in prehistoric New Zealand. Unpublished MA thesis, Auckland University.

Howe, K.R.

1977 The fate of the 'savage' in Pacific historiography. The New Zealand Journal of History 11:137-154. 
Inside Austronesian Houses

Jackson, Michael

1972 Aspects of symbolism and composition in Maori art. Bijdragen tot de Taal-, Land-en Volkenkunde 128(1):33-80.

Johansen, J. Prytz

1954 The Maori and his religion in its non-ritualistic aspects. Copenhagen: Ejnar Munksgaard.

Kernot, Bernie

1983 The meeting house in contemporary New Zealand. In Sidney M. Mead and Bernie Kernot (eds) Art and artists of Oceania, pp.181-197. Palmerston North: Dunmore.

Lévi-Strauss, Claude

1982 The way of the masks (translated by Sylvia Modelski). Seattle: University of Washington Press. (Orig. pub. Paris, 1979.)

1987 Anthropology and myth: lectures, 1951-1982 (translated by Roy Willis). Oxford: Basil Blackwell. (Orig. pub. Paris, 1984.)

Mead, Sidney M.

1976 The production of native art and craft objects in contemporary New Zealand society. In Nelson H.H. Graburn (ed.) Ethnic and tourist arts: cultural expressions from the fourth world, pp.285-298. Berkeley: University of California Press.

Metge, Joan

1976 The Maoris of New Zealand: Rautahi (Revised edition). London: Routledge \& Kegan Paul. (Orig. pub. 1967.)

Neich, Roger

1983 The veil of orthodoxy: Rotorua Ngati Tarawhai woodcarving in a changing context. In Sidney M. Mead and Bernie Kernot (eds) Art and artists of Oceania, pp.244-265. Palmerston North: Dunmore.

1984 The complementarity of history and art in T tāmare meeting-house, marumutu Marae, p tiki. The Journal of the Polynesian Society 93:5-37.

Prickett, Nigel

1987 Shelter and security: houses and settlements. In John Wilson (ed.) From the beginning: the archaeology of the Maori, pp.95-108. Auckland: Penguin in association with the New Zealand Historic Places Trust.

Salmond, Anne

1975 Hui: a study of Maori ceremonial gatherings. Wellington: Reed. 
1978 Te Ao Tawhito: a semantic approach to the traditional Maori cosmos. The Journal of the Polynesian Society 87:5-28.

Shirres, Michael P.

1982 Tapu. The Journal of the Polynesian Society 91:29-51.

Sorrenson, M.P.K.

1979 Maori origins and migrations: the genesis of some Pakeha myths and legends. Auckland: Auckland University Press.

Walker, Ranginui

1977 Marae: a place to stand. In Michael King (ed.) Te Ao Hurihuri, the world moves on: aspects of Maoritanga, pp.21-34. Wellington: Hicks Smith \& Sons. (Orig. pub. 1975.)

\section{Webster, Steven}

1975 Cognatic descent groups and the contemporary Maori: a preliminary reassessment. The Journal of the Polynesian Society 84:121-152.

Williams, H.W.

1896 The Maori whare: notes on the construction of a Maori house. The Journal of the Polynesian Society 5:145-154.

\section{Notes}

I thank Aletta Biersack, James J. Fox and Michael Reilly for comments on an earlier version of this paper.

${ }^{1}$ In its quest for a distinctive national image the New Zealand population as a whole eagerly embraces Maori art and craft (Mead 1976).

2 Throughout this paper when I refer to locations on the right-hand and left-hand side of the meeting house, I am positioned inside the building facing towards the front wall.

3 I was convinced, however, that it had just taken him a couple of days to think of a satisfactory answer.

${ }^{4}$ Metge (1976:232-235) conceived of tapu and noa as a complementary opposition, on the basis of which she described, for example, the meeting-house as noa in contrast to the marae aatea, whereas both the meeting-house and the marae aatea were tapu in contrast to the dining hall. However, in my opinion, a meeting-house can never be noa, not even after the tapu has been lifted. It may be less tapu than the marae aatea, but it can never be noa under any circumstances.

5 In Tainui, where I did my fieldwork, however, coffins were routinely taken inside the meeting-house, except on sunny days, so I cannot really address that question.

6 'Hori', a Maori transliteration of 'George', is a New Zealand colloquialism used as a derogatory term for Maori people.

7 Relevant in this context is the myth of the demi-god Maui, who attempted to procure immortality for humanity by beguiling Hine-nui-te-Po (Great-lady-of-the-Night), the goddess of death. While she was asleep Maui wanted to enter her vagina and emerge by her mouth after cutting out her heart on the way through. However, Hine-nui-te-Po awoke, brought her thighs together and Maui was strangled. Since then death has remained in the world (Grey 1971:21-23).

8 For a comparative overview of the transformation of the meeting-house in Tuvalu, see Goldsmith (1985). Goldsmith, however, situates his analysis in a broader theoretical perspective. 
9 This belief may have misled anthropologists like Anne Salmond, who insufficiently situated her analysis of the meeting-house in an historical perspective. She wrote about the meeting-house as a static edifice that invoked timelessness during ceremonies performed within it. However, she neglected to examine the implications of the historical fact that the meeting-house itself was a post-European development. In a later publication, Te Ao Tawhito ('The ancient Maori world'), she mentioned in passing that the interpretation of the meeting-house as the representation of an ancestor may have been introduced only recently (Salmond 1978:24). However, she failed to explore the consequences of that statement, which she only made to explain the contradictions in the otherwise consistent model of the Maori cosmos she claimed to have discovered. Whether the logic of the model Salmond expounded was Maori logic remains to be seen (Shirres 1982:49).

10 For a more detailed analysis of the changes in style of carving, see Neich (1983). 


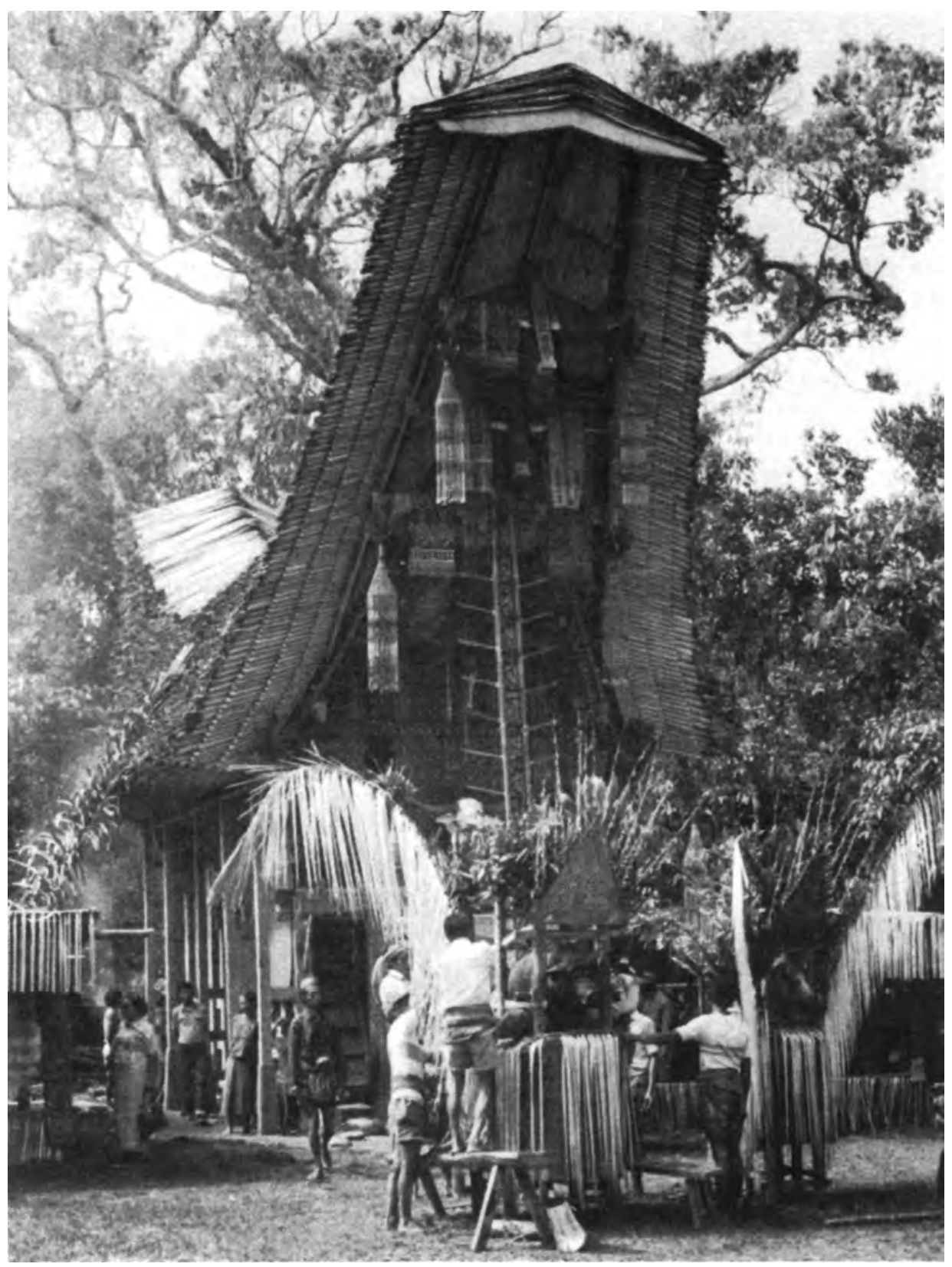

The renowned Toraja tongkonan (origin-house) of Nonongan, hung with precious heirlooms for a ceremony to celebrate completion of its rebuilding (Tana Toraja, Sulawesi, 1983) 